\title{
Ocular effects of retrobulbar block with different local anesthetics in healthy dogs
}

\section{Repercussões oculares do bloqueio retrobulbar com diferentes anestésicos locais em cães normais}

\author{
Cristiane dos Santos Honsho ${ }^{1 *}$; Leandro Guimarães Franco ${ }^{2}$; \\ Sofia de Amorim Cerejo ${ }^{3}$; Murici Belo Segato ${ }^{3}$; Marco Antônio Ferreira ${ }^{4}$; \\ Aline Adriana Bolzan ${ }^{5}$, Celina Tie Nishimori Duque ${ }^{2}$; José Luiz Laus ${ }^{6}$
}

\begin{abstract}
The objective of this study was to evaluate the ocular effects, the feasibility and the quality of retrobulbar block using the inferior temporal technique with different local anesthetics applied with the Tuohy epidural needle in dogs. Eight dogs were included in the experiment and each one was studied four times, with interval of 15 days between the treatments: Lido - $2 \%$ lidocaine, Ropi - $0.75 \%$ ropivacaine, Bupi - $0.5 \%$ racemic bupivacaine and Levo - $0.75 \%$ levobupivacaine. Except for the ropivacaine, all of the local anesthetics contained epinephrine at 1:200.000. The blocks were performed in the right eyes immediately after anesthetic induction, and the left eyes were not blocked and were used as controls. The intraocular pressure, tear production and corneal sensitivity were evaluated before any procedure (T0), $30 \mathrm{~min}$ after premedication (TMPA), $30 \mathrm{~min}$ after anesthetic induction (T30), after recovery from anesthesia (TREC), every $60 \mathrm{~min}$ up to $360 \mathrm{~min}$ and 12 and $24 \mathrm{~h}$ after the block. The pupil diameter was evaluated at the same time points, excepted at $\mathrm{T} 0$. The maximum pupillary dilatation was observed in Lido group at T120 followed by Ropi at TREC, and Bupi and Levo at T30. All of the anesthetics maintained eye pressure within acceptable levels for normal dogs and significantly reduced tear production. Tear production returned earliest in group Lido, followed by Bupi, Ropi and Levo. The corneal sensitivity returned earliest in group Lido, followed by Ropi, Bupi and Levo. The retrobulbar block using the temporal inferior technique proved to be feasible and safe, although lubrication of the ocular surface is suggested.
\end{abstract}

Key words: Bupivacaine, dogs, levobupivacaine, lidocaine, ropivacaine

\section{Resumo}

O objetivo deste estudo foi avaliar os efeitos oculares, a exequibilidade e qualidade do bloqueio retrobulbar pela técnica inferior temporal, em cães, com diferentes anestésicos locais empregando-se agulha epidural de Tuohy. Oito cães foram incluídos no experimento e cada um foi estudado quatro vezes, com intervalo de 15 dias entre os tratamentos: Lido - lidocaína a $2 \%$; Ropi - ropivacaína a 0,5\%, Bupi - bupivacaína racêmica a $0,5 \%$ e Levo - levobupivacaína a $0,75 \%$. Com exceção da ropivacaína,

${ }^{1}$ Prof ${ }^{a}$, Universidade de Franca, UNIFRAN, Franca, SP, Brasil. E-mail: cristiane.honsho@unifran.edu.br

2 Profs., Universidade Federal de Goiás, UFG, Jataí, GO, Brasil. E-mail: lg.franco@yahoo.com.br; celinatie@yahoo.com.br

${ }^{3}$ Discentes de Pós-graduação, UNIFRAN, Franca, SP, Brasil. E-mail: socerejo@uol.com.br; muricisegato@yahoo.com.br

${ }^{4}$ Prof., Faculdade de Ciências Sociais e Agrárias de Itapeva, Itapeva, SP, Brasil. E-mail: kaienavetmarco@gmail.com

${ }^{5}$ Prof ${ }^{a}$, Universidade de São Paulo, São Paulo, USP, SP, Brasil. E-mail: alinebolzan@usp.br

${ }^{6}$ Prof., Universidade Estadual Paulista “Júlio de Mesquita Filho”, Campus Jaboticabal, UNESP, Jaboticabal, SP, Brasil. E-mail: jllaus@fcav.unesp.br

* Author for correspondence 
todos os anestésicos continham epinefrina 1:200.000. Os bloqueios foram realizados nos olhos direitos dos animais imediatamente após a indução anestésica, e os olhos esquerdos, não bloqueados, foram utilizados como controle. Avaliou-se a pressão intraocular, a produção lacrimal e a sensibilidade corneal antes de qualquer procedimento (T0), 30 min após a medicação pré-anestésica (TMPA), 30 min após a indução anestésica (T30), após a recuperação da anestesia (TREC), a cada 60 min até 360 min e 12 e 24 h após o bloqueio. O diâmetro pupilar foi avaliado nos mesmos momentos, exceto no T0. A máxima dilatação pupilar foi observada no grupo Lido seguida pelos grupos Ropi, Bupi e Levo. Todos os anestésicos mantiveram a pressão ocular dentro dos níveis normais para cães e reduziram significativamente a produção lacrimal. A produção lacrimal retornou ao normal primeiramente no grupo Lido, seguida pelos grupos Bupi, Ropi e Levo. O retorno da sensibilidade corneal ocorreu primeiramente no grupo Lido, seguido pelos grupos Ropi, Bupi e Levo. O bloqueio retrobulbar pela técnica inferior temporal demonstrou ser exequível e seguro, embora o uso de lubrificantes oculares seja sugerido.

Palavras-chave: Bupivacaína, cães, levobupivacaína, lidocaína, ropivacaína

\section{Introduction}

In contrast to human ophthalmic surgery, in which different anesthetic modalities such as retrobulbar, peribulbar, subconjunctival, topical and sub-Tenon may be utilized (COELHO et al., 2005), such surgery in dogs requires chemical restraint, which, when added to the safety of inhalational general anesthesia, outweighs the use of regional blocks. The ocular blocks useful in humans (WONG, 1993; GILLART; DUALÉ; CURT, 2002) and large animals (COLLINS et al., 1995; SKARDA, 1996; MUIR III et al., 2001; GILGER; DAVIDSON, 2002) have been shown to be effective and easy to administer when combined with sedation or general anesthesia (OLIVA; BEVILACQUA, 2005), and they can be used to minimize the depressant effects caused by the deep planes of anesthesia (MUIR III et al., 2001).

Regional anesthesia for use in the eye, in addition to providing analgesia, helps reduce the occurrence of oculocardiac reflex and has the advantage of low cost (GILLART; DUALÉ; CURT, 2002). Among the various techniques of anesthesia, regional blocks in dogs represent a viable alternative adjuvant for anesthesia in eye surgery (KANEMAKI et al., 2000; OLIVA; ANDRADE; GABAS, 2003; ACCOLA et al., 2006; OLIVA et al., 2010). Accola et al. (2006) studied two techniques of retrobulbar block and one of peribulbar block in dogs and concluded that the inferior temporal technique was superior to the other techniques evaluated. Their characteristics included easy implementation, a wide distribution of anesthetic agents on the retrobulbar space. Thus, the aim of this study was to evaluate the ocular effects, feasibility and quality of retrobulbar block by the inferior temporal technique with different local anesthetics using the Tuohy epidural needle in dogs.

\section{Materials and Methods}

This study was performed with the permission of the Animal Ethics Committee of the University of Franca, protocol 027/07A, and was in strict accordance with the tenets of the Association for Research in Vision and Ophthalmology (ARVO, 2013).

\section{Animals}

Eight clinically healthy mixed-breed dogs of either sex (five females and three males), weighing $19.9 \pm 6.4 \mathrm{~kg}$ (mean \pm standard deviation; SD) were used. The dogs were considered to be healthy on the basis of a physical examination and standard laboratory tests (packed cell volume, total solids, urea, creatinine, alanine aminotransferase and alkaline phosphatase). In particular, all dogs' eyes were examined by a veterinary ophthalmologist 
before the experiment, and the examinations included direct ophthalmoscopy, the fluorescein test, the Schirmer tear test and a measurement of intraocular pressure using an applanation tonometer. The corneal sensitivity was evaluated in all animals with the Cochet-Bonnet aesthesiometer using as a standard of positive response for the nonanesthetized animal, the nylon yarn with $25 \mathrm{~mm}$ length.

Each dog was studied on four occasions using a randomized crossover design, with a minimum of 15 days between experiments. The treatments were designated as Lido (lidocaine - 2\%) (2\% Xylestesin, Cristália), Ropi (ropivacaine - 0.75\%) (0.75\% Ropi, Cristália), Bupi (bupivacaine - 0.5\%) (0.5\% Neocaína, Cristália), and Levo (levobupivacaine $0.75 \%)(0.75 \%$ Novabupi, Cristália). Except for the ropivacaine, all of the local anesthetics contained epinephrine at 1:200.000.

\section{Anaesthesia}

The animals were premedicated with a mixture of $0.05 \mathrm{mg} / \mathrm{kg}$ of acepromazine hydrochloride ( $0.2 \%$ Acepran, Univet) and $2 \mathrm{mg} / \mathrm{kg}$ of meperidine (Dolosal, Cristália) administered intramuscularly. After aseptic preparation, a 22G peripheral vascular catheter (Cateter 22G, Nipro) was placed in the right cephalic vein. Anesthetic induction was performed 30 min after premedication (MPA) by intravenous (IV) application of $3.5 \mathrm{mg} / \mathrm{kg}$ of propofol (Propovan, Cristália) and $1.0 \mu \mathrm{g} / \mathrm{kg}$ of fentanyl (Fentanest, Cristália) (PIRES et al., 2000).

The anesthesia was maintained by a constantrate infusion of $0.4 \mathrm{mg} / \mathrm{kg} / \mathrm{min}$ of propofol and 0.2 $\mu \mathrm{g} / \mathrm{kg} / \mathrm{min}$ of fentanyl supplied by infusion pumps (Pump infusion mod. ST 680, Samtronic). The animals were intubated for administration of $100 \%$ oxygen at a rate of $30 \mathrm{~mL} / \mathrm{kg} / \mathrm{min}$ with a semiclosed anesthetic circuit and positioned in sternal recumbency on a warming blanket (T-pump 500 and $\mathrm{TP} 22 \mathrm{G}$, Gaymar) heated to $38^{\circ} \mathrm{C}$. The dorsal pedal artery was catheterized to measure mean arterial pressure (HASKINS, 2007). During anesthesia, the animals received $5 \mathrm{~mL} / \mathrm{kg} / \mathrm{h}$ of Ringer's lactate.

The animals were monitored during general anesthesia by evaluation of the mean arterial pressure, heart rate, respiratory rate, partial pressure of carbon dioxide at the end of expiration and oxyhemoglobin saturation, and the complications were recorded to detect changes in the cardiorespiratory system that might arise from the anesthetic block.

\section{Retrobulbar block}

The retrobulbarblockwas performed immediately after anesthetic induction and was based on the inferior temporal technique described by Accola et al. (2006), using a 20G Tuohy needle (Tuohy needle, Unisis). The needle was bent at an angle of approximately $20^{\circ}$ at its midpoint. Assuming as a reference the inferior orbital rim, the eyelid (in the junction between the middle and temporal thirds) was pierced with a needle held parallel to the animal's snout. To minimize the risk of bulb perforation during the procedure, the needle was centered using a mosquito clamp affixed to the superior bulbar conjunctiva. Subsequently, the needle was directed toward the in-nasal dorsum to the apex of the orbit. The final volume of local anesthetics administered was $2 \mathrm{~mL}$ for $30 \mathrm{~s}$, regardless of treatment group. The general anesthesia was maintained for $40 \mathrm{~min}$ after induction of the block.

\section{Evaluations}

Ocular assessments were performed by the same person. The pupillary diameter was measured with a digital caliper (150 mm digital caliper, Digimess), intraocular pressure (IOP) was measured with an applanation tonometer (Avia, Reichert) and tear production was assessed with the Schirmer tear test (Schirmer test, Ophthalmos). The evaluations were performed in both eyes immediately before any procedure (T0), $30 \mathrm{~min}$ after preanesthetic medication (TMPA), $30 \mathrm{~min}$ after anesthetic 
induction (T30), after anesthetic recovery (TREC 60 min after anesthetic induction), each 60 min until $360 \mathrm{~min}$ had passed and 12 and $24 \mathrm{~h}$ after the block. The pupillary diameter was not evaluated at T0 due to the difficulty of performing the procedure in nonanesthetized animals. The unblocked, contralateral eyes of the animals were used as control. The adverse effects of anesthetic administration were evaluated at all time points mentioned above and at 12 and $24 \mathrm{~h}$ after the block.

A Cochet-Bonnet aesthesiometer (CochetBonnet, Luneau Opthalmologie) was used to measure corneal touch threshold. Was considered a positive response when the nylon yarn was adjusted to $0.5 \mathrm{~mm}$ length and was observed blepharoespasm when was in contact with the central cornea. The corneal sensitivity was assessed at T0, TMPA, T30, TREC and every 60 min until a positive response to the test was detected, and the time of sensation recovery was recorded.

\section{Statistical analylsis}

The data for pupillary diameter, intraocular pressure, Schirmer tear test and corneal sensitivity are presented as the mean \pm standard deviations (SD). The computer program Sigma Stat - Windows (4.0 Sigma Stat, Systat) was employed to analyze the data. The Kolmogorov-Smirnov test was used to determine whether the data were normally distributed.

The results with normal distributions were submitted to the Analysis of Variance (ANOVA) for repeated measurements, followed by the StudentNewman-Keuls (SNK) test for a comparison of the intervals inside each group, and a one-way ANOVA followed by the SNK test was used for comparison among the groups for each interval. For the data that did not have a normal distribution, the Friedman test followed by the SNK test was used. To compare the data of the same treatment between the blocked eyes and control eyes, we used the paired t-test. A significance level of $5 \%(P<0.05)$ was used for the experiment.

\section{Results}

The exposure of globe in all dogs was adequate and similar in both treatments. Chemosis was observed in three animals in Lido and Ropi, in four animals in Bupi and in six animals in Levo. One animal showed slight chemosis after administration of all local anesthetics. In Ropi, four animals showed intense conjunctival hyperemia during the trial period. Blepharospasm and itching were observed in one animal in Levo and in three in Ropi. One animal in Ropi and two in Levo developed corneal ulcers that were verified at T300 and $10 \mathrm{~h}$ after the blockade. Two animals in Bupi had medial strabismus 15 min after the blockade and dyscoria at T360 in the blocked eye. Two animals in Levo presented lateral strabismus at T240. In Ropi, the appearance of the corneal ulcer was preceded by discomfort with blepharospasm and signs of severe itching. In one animal in Bupi, conjunctival hemorrhage was observed after the procedure. When evaluated at 12 and $24 \mathrm{~h}$ after the block, no other complications were observed.

The retrobulbar block (Table 1) led to a significantly increased pupillary diameter in all treatments compared to the control eyes, and this effect remained throughout the evaluation period. The maximum pupillary dilatation was observed in dogs treated with lidocaine $(10.88 \pm 0.91 \mathrm{~mm})$ at T120 followed by ropivacaine $(10.87 \pm 0.66$ $\mathrm{mm})$ in TREC, bupivacaine $(10.49 \pm 0.80 \mathrm{~mm})$ and levobupivacaine $(10.11 \pm 0.84 \mathrm{~mm})$ at T30. Significant differences in pupillary diameter were observed only between ropivacaine and levobupivacaine in TREC $(P=0.018)$. 
Table 1. Means \pm SD of pupillary diameter (in millimeters) of blocked (BE) and control eyes (NBE), of dogs after retrobulbar block with 2\% lidocaine (Lido); 0.75\% ropivacaine (Ropi), 0.5\% bupivacaine (Bupi) or 0.75\% levobupivacaine (Levo).

\begin{tabular}{|c|c|c|c|c|c|c|c|c|c|}
\hline Group & Eye & TMPA & T30 & TREC & T120 & T180 & T240 & T300 & T360 \\
\hline \multirow{2}{*}{ Lido } & $\mathbf{B E}$ & $\begin{array}{c}4.10 \\
{[1.05]}\end{array}$ & $\begin{array}{c}10.40^{* \dagger} \\
{[0.46]}\end{array}$ & $\begin{array}{c}10.14^{* \text { tab }} \\
{[0.61]}\end{array}$ & $\begin{array}{c}10.88^{* \dagger} \\
{[0.91]}\end{array}$ & $\begin{array}{l}8.86^{* \dagger} \\
{[2.96]}\end{array}$ & - & - & - \\
\hline & NBE & $\begin{array}{c}4.05 \\
{[1.09]}\end{array}$ & $\begin{array}{l}2.56^{*} \\
{[0.73]}\end{array}$ & $\begin{array}{c}3.01 \\
{[0.86]}\end{array}$ & $\begin{array}{c}4.45^{\S} \\
{[1.28]}\end{array}$ & $\begin{array}{l}4.71^{\S} \\
{[1.31]}\end{array}$ & - & - & - \\
\hline \multirow{2}{*}{ Ropi } & BE & $\begin{array}{c}4.28 \\
{[0.74]}\end{array}$ & $\begin{array}{c}9.85 \\
{[3.09]}\end{array}$ & $\begin{array}{c}10.87^{* \text { *a }} \\
{[0.66]}\end{array}$ & $\begin{array}{l}9.62 * \dagger \\
{[1.86]}\end{array}$ & $\begin{array}{l}7.36^{* \S} \\
{[3.39]}\end{array}$ & $\begin{array}{l}5.75^{\S} \\
{[3.12]}\end{array}$ & $\begin{array}{l}7.08 * \S \\
{[3.29]}\end{array}$ & $\begin{array}{l}8.91^{* \dagger} \\
{[3.45]}\end{array}$ \\
\hline & NBE & $\begin{array}{c}4.46 \\
{[1.04]}\end{array}$ & $\begin{array}{c}4.03 \\
{[3.05]}\end{array}$ & $\begin{array}{c}4.09 \\
{[1.14]}\end{array}$ & $\begin{array}{c}6.88 \\
{[2.10]}\end{array}$ & $\begin{array}{c}6.68 \\
{[1.82]}\end{array}$ & $\begin{array}{c}7.11 \\
{[1.66]}\end{array}$ & $\begin{array}{c}6.20 \\
{[1.47]}\end{array}$ & $\begin{array}{c}5.42 \\
{[1.00]}\end{array}$ \\
\hline \multirow{2}{*}{ BUPI } & BE & $\begin{array}{c}4.13 \\
{[1.04]}\end{array}$ & $\begin{array}{c}10.49^{* \dagger} \\
{[0.80]}\end{array}$ & $\begin{array}{c}10.17^{* \dagger \mathrm{ab}} \\
{[1.26]}\end{array}$ & $\begin{array}{l}9.50^{* \dagger} \\
{[2.03]}\end{array}$ & $\begin{array}{l}5.97^{\S} \\
{[4.06]}\end{array}$ & $\begin{array}{l}6.06^{\S} \\
{[4.45]}\end{array}$ & $\begin{array}{c}6.95 \\
{[4.46]}\end{array}$ & $\begin{array}{c}6.37 \\
{[4.38]}\end{array}$ \\
\hline & NBE & $\begin{array}{c}4.10 \\
{[1.19]}\end{array}$ & $\begin{array}{c}2.82 \\
{[0.73]}\end{array}$ & $\begin{array}{c}3.77 \\
{[0.92]}\end{array}$ & $\begin{array}{l}5.80 * \S \\
{[1.69]}\end{array}$ & $\begin{array}{c}5.44^{\S} \\
{[1.42]}\end{array}$ & $\begin{array}{c}5.35^{\S} \\
{[1.29]}\end{array}$ & $\begin{array}{c}5.34^{\S} \\
{[1.35]}\end{array}$ & $\begin{array}{c}5.33^{\S} \\
{[0.97]}\end{array}$ \\
\hline \multirow{2}{*}{ Levo } & BE & $\begin{array}{c}3.85^{\dagger} \\
{[0.78]}\end{array}$ & $\begin{array}{c}10.11^{* \dagger} \\
{[0.84]}\end{array}$ & $\begin{array}{l}9.60 *+b \\
{[1.03]}\end{array}$ & $\begin{array}{l}9.42^{* \dagger} \\
{[1.20]}\end{array}$ & $\begin{array}{l}7.14^{* \dagger} \\
{[2.16]}\end{array}$ & $\begin{array}{l}5.89 * \S \\
{[2.76]}\end{array}$ & $\begin{array}{l}5.99 * \S \\
{[3.39]}\end{array}$ & $\begin{array}{c}6.95^{*} \\
{[3.38]}\end{array}$ \\
\hline & NBE & $\begin{array}{c}3.48 \\
{[0.75]}\end{array}$ & $\begin{array}{c}2.59 \\
{[0.91]}\end{array}$ & $\begin{array}{c}3.83 \\
{[1.01]}\end{array}$ & $\begin{array}{c}4 \\
{[0.55]}\end{array}$ & $\begin{array}{c}3.96 \\
{[0.93]}\end{array}$ & $\begin{array}{c}4.02 \\
{[0.66]}\end{array}$ & $\begin{array}{c}4.37 \\
{[0.93]}\end{array}$ & $\begin{array}{c}4.63 \\
{[2.85]}\end{array}$ \\
\hline
\end{tabular}

* Indicates significant difference from other time points with TMPA. \$Indicates significant difference from the other time points with T60. Indicates significant difference between blocked and control eyes within each treatment over time. ${ }^{\mathrm{a}, \mathrm{b}}$ Indicates significant difference between treatments over time $(\mathrm{p}<0.05)$.

Source: Elaboration of the authors.

The baseline mean IOP recorded was $17.47 \pm$ $3.69 \mathrm{mmHg}$ (Table 2). No differences were found between treatments at different time intervals, with mean intraocular pressure in accordance with normal values to the literature $(P>0.05)$ (SLATTER, 2005). In Lido, the intraocular pressure increased, showing significant differences between the control and the blocked eye $(P=0.028)$ and the baseline values at T30 $(P=0.002)$, returning to baseline levels at subsequent times. In the Ropi group, statistically significant reductions in IOP were observed between T180 $(P=0.007)$ and T300 $(P=0.003)$. 
Table 2. Mean \pm SD intraocular pressure (mmHg) of the anesthetic blocked (BE) and control eyes (NBE) of dogs after retrobulbar block with 2\% lidocaine (Lido); 0.75\% ropivacaine (Ropi), 0.5\% bupivacaine (Bupi) or 0.75\% levobupivacaine (Levo).

\begin{tabular}{|c|c|c|c|c|c|c|c|c|c|c|}
\hline Group & Eye & T0 & TMPA & T30 & TREC & T120 & T180 & T240 & T300 & T360 \\
\hline \multirow{2}{*}{ Lido } & $\mathbf{B E}$ & $\begin{array}{c}17 \\
{[4.3]}\end{array}$ & $\begin{array}{c}16 \\
{[3.0]}\end{array}$ & $\begin{array}{c}18^{\dagger} \\
{[2.4]}\end{array}$ & $\begin{array}{c}18 \\
{[2.1]}\end{array}$ & $\begin{array}{c}18^{\dagger} \\
{[2.7]}\end{array}$ & $\begin{array}{c}16 \\
{[2.7]}\end{array}$ & - & - & - \\
\hline & NBE & $\begin{array}{c}17 \\
{[3.4]}\end{array}$ & $\begin{array}{c}16 \\
{[1.5]}\end{array}$ & $\begin{array}{l}21^{*} \\
{[3.1]}\end{array}$ & $\begin{array}{c}16 \\
{[1.8]}\end{array}$ & $\begin{array}{c}16 \\
{[1.6]}\end{array}$ & $\begin{array}{c}16 \\
{[1.5]}\end{array}$ & - & - & - \\
\hline \multirow{2}{*}{ Ropi } & $\mathbf{B E}$ & $\begin{array}{c}18 \\
{[4.6]}\end{array}$ & $\begin{array}{c}16 \\
{[3.7]}\end{array}$ & $\begin{array}{c}16^{\dagger} \\
{[4.1]}\end{array}$ & $\begin{array}{c}15^{\dagger} \\
{[2.3]}\end{array}$ & $\begin{array}{c}16^{\dagger} \\
{[2.6]}\end{array}$ & $\begin{array}{l}13 * \dagger \\
{[2.4]}\end{array}$ & $\begin{array}{c}14 \\
{[3.9]}\end{array}$ & $\begin{array}{l}13^{* \dagger} \\
{[4.0]}\end{array}$ & $\begin{array}{c}14 \\
{[2.3]}\end{array}$ \\
\hline & NBE & $\begin{array}{c}18 \\
{[4.5]}\end{array}$ & $\begin{array}{c}16 \\
{[2.9]}\end{array}$ & $\begin{array}{c}19 \\
{[3.6]}\end{array}$ & $\begin{array}{c}18 \\
{[2.6]}\end{array}$ & $\begin{array}{c}19 \\
{[4.1]}\end{array}$ & $\begin{array}{c}18 \\
{[4.8]}\end{array}$ & $\begin{array}{c}17 \\
{[8.2]}\end{array}$ & $\begin{array}{c}18 \\
{[4.0]}\end{array}$ & $\begin{array}{c}17 \\
{[3.9]}\end{array}$ \\
\hline \multirow{2}{*}{ Bupi } & $\mathbf{B E}$ & $\begin{array}{c}18 \\
{[3.4]}\end{array}$ & $\begin{array}{c}19 \\
{[3.4]}\end{array}$ & $\begin{array}{c}17 \\
{[4.1]}\end{array}$ & $\begin{array}{c}17 \\
{[3.2]}\end{array}$ & $\begin{array}{c}19 \\
{[3.4]}\end{array}$ & $\begin{array}{c}16 \\
{[4.4]}\end{array}$ & $\begin{array}{c}15 \\
{[4.3]}\end{array}$ & $\begin{array}{c}16^{\dagger} \\
{[4.2]}\end{array}$ & $\begin{array}{c}16 \\
{[2.1]}\end{array}$ \\
\hline & NBE & $\begin{array}{c}19 \\
{[4.0]}\end{array}$ & $\begin{array}{c}16 \\
{[6.0]}\end{array}$ & $\begin{array}{c}17 \\
{[9.4]}\end{array}$ & $\begin{array}{c}18 \\
{[2.7]}\end{array}$ & $\begin{array}{c}18 \\
{[2.9]}\end{array}$ & $\begin{array}{c}18 \\
{[4.0]}\end{array}$ & $\begin{array}{c}17 \\
{[3.4]}\end{array}$ & $\begin{array}{c}19 \\
{[4.3]}\end{array}$ & $\begin{array}{c}16 \\
{[1.9]}\end{array}$ \\
\hline \multirow{2}{*}{ Levo } & $\mathbf{B E}$ & $\begin{array}{c}18^{\dagger} \\
{[2.4]}\end{array}$ & $\begin{array}{c}17 \\
{[2.6]}\end{array}$ & $\begin{array}{c}18 \\
{[3.3]}\end{array}$ & $\begin{array}{c}18 \\
{[3.6]}\end{array}$ & $\begin{array}{c}16 \\
{[2.8]}\end{array}$ & $\begin{array}{c}17 \\
{[2.9]}\end{array}$ & $\begin{array}{c}16 \\
{[2.6]}\end{array}$ & $\begin{array}{c}16 \\
{[3.9]}\end{array}$ & $\begin{array}{c}15 \\
{[2.9]}\end{array}$ \\
\hline & NBE & $\begin{array}{c}16 \\
{[2.9]}\end{array}$ & $\begin{array}{c}19 \\
{[3.3]}\end{array}$ & $\begin{array}{c}18 \\
{[3.9]}\end{array}$ & $\begin{array}{c}18 \\
{[2.9]}\end{array}$ & $\begin{array}{c}16 \\
{[1.9]}\end{array}$ & $\begin{array}{c}17 \\
{[3.7]}\end{array}$ & $\begin{array}{c}17 \\
{[2.7]}\end{array}$ & $\begin{array}{c}16 \\
{[4.1]}\end{array}$ & $\begin{array}{c}16 \\
{[3.1]}\end{array}$ \\
\hline
\end{tabular}

* Indicates significant difference from other time points with baseline (T0). ${ }^{\S}$ Indicates significant difference from the other time points with T60. ${ }^{\dagger}$ Indicates significant difference between blocked and control eyes within each treatment over time. ${ }^{\mathrm{a}, \mathrm{b}}$ Indicates significant difference between treatments over time $(\mathrm{p}<0.05)$.

Source: Elaboration of the authors.

Tear production decreased significantly in all treatments over several time points compared to the baseline for both the blocked and control eyes. Except for the Lido, the reduction in tear production was significantly greater in treated eyes compared to control from T30 in Bupi $(P=0.007)$ and Levo $(P$ $=0.018)$ and from TREC $(P=0.016)$ in Ropi. These significant differences were observed until T180 $(P<0.01)$ in Bupi, T300 $(P<0.001)$ in Ropi and T360 $(P=0.04)$ in Levo. General anesthesia was observed to trigger a reduction in tear production in the control eyes in all treatments (Table 3). In the eyes that were not blocked, tear production resumed earlier than it did in the blocked eyes. The differences compared to the baseline values were no longer observed after T120 in Lido, Bupi and Levo and T180 in Ropi $(P>0.05)$. In the blocked eyes, tear production was significantly reduced in Lido until T180 $(P=0.007)$. For the other treatments, this reduction remained significant at all time points $(P<0.03)$. In comparing treatments, all anesthetics, with the exception of lidocaine, promoted a lasting reduction in tear production, more pronounced in Levo and Ropi at T300 compared to Bupi $(P<0.05)$. 
Table 3. Mean \pm SD of tear production (millimeters per minute) of blocked (BE) and control eyes (NBE) of dogs after retrobulbar block with 2\% lidocaine (Lido); 0.75\% ropivacaine (Ropi), 0.5\% bupivacaine (Bupi) or 0.75\% levobupivacaine (Levo).

\begin{tabular}{|c|c|c|c|c|c|c|c|c|c|c|}
\hline Group & Eye & T0 & TMPA & T30 & TREC & T120 & T180 & T240 & T300 & T360 \\
\hline \multirow{2}{*}{ Lido } & $\mathbf{B E}$ & $\begin{array}{l}20.6 \\
{[3.7]}\end{array}$ & $\begin{array}{c}10.0 \\
{[7.3]}\end{array}$ & $\begin{array}{l}3.8^{* a} \\
{[2.9]}\end{array}$ & $\begin{array}{l}4.0^{* \mathrm{a}} \\
{[4.4]}\end{array}$ & $\begin{array}{l}1.6^{* \mathrm{a}} \\
{[3.1]}\end{array}$ & $\begin{array}{c}9.1 * \S a \\
{[8.3]}\end{array}$ & $\begin{array}{l}15.5^{\text {§a }} \\
{[5.6]}\end{array}$ & - & - \\
\hline & NBE & $\begin{array}{l}21.9 \\
{[3.3]}\end{array}$ & $\begin{array}{c}10.6 \\
{[7.9]}\end{array}$ & $\begin{array}{l}4.0^{*} \\
{[2.7]}\end{array}$ & $\begin{array}{l}5.8^{*} \\
{[6.8]}\end{array}$ & $\begin{array}{l}7.0^{* \S} \\
{[5.0]}\end{array}$ & $\begin{array}{l}14.1^{\S} \\
{[6.4]}\end{array}$ & $\begin{array}{c}17.0^{\S} \\
{[4]}\end{array}$ & - & - \\
\hline \multirow{2}{*}{ Ropi } & $\mathbf{B E}$ & $\begin{array}{l}20.1 \\
{[3.6]}\end{array}$ & $\begin{array}{l}8.9^{*} \\
{[7.3]}\end{array}$ & $\begin{array}{c}0.1^{* a \mathrm{ab}} \\
{[0.4]}\end{array}$ & $\begin{array}{c}0^{* \dagger \dagger} \mathrm{b} \\
{[0]}\end{array}$ & $\begin{array}{c}0^{* \dagger \mathrm{b}} \\
{[0]}\end{array}$ & $\begin{array}{c}3.1^{1 * a, b} \\
{[8.1]}\end{array}$ & $\begin{array}{c}3.9 * \$+\mathrm{b} \\
{[4.7]}\end{array}$ & $\begin{array}{c}7.6^{* \$ \uparrow a} \\
{[6.5]}\end{array}$ & $\begin{array}{c}11.9^{* \S} \\
{[6.4]}\end{array}$ \\
\hline & NBE & $\begin{array}{l}21.1 \\
{[3.5]}\end{array}$ & $\begin{array}{l}7.5^{*} \\
{[5.1]}\end{array}$ & $\begin{array}{l}3.3 * \\
{[4.6]}\end{array}$ & $\begin{array}{c}4^{*} \\
{[1.9]}\end{array}$ & $\begin{array}{l}11.4^{*} \\
{[7.3]}\end{array}$ & $\begin{array}{l}14.3^{*} \\
{[6.7]}\end{array}$ & $\begin{array}{l}15.6 \\
{[7.1]}\end{array}$ & $\begin{array}{l}17.9^{\S} \\
{[4.5]}\end{array}$ & $\begin{array}{l}14.8^{\S} \\
{[8.3]}\end{array}$ \\
\hline \multirow{2}{*}{ Bupi } & BE & $\begin{array}{l}20.3 \\
{[5.2]}\end{array}$ & $\begin{array}{l}9.5^{*} \\
{[6.3]}\end{array}$ & $\begin{array}{c}0^{* \dagger b} \mathrm{~b} \\
{[0]}\end{array}$ & $\begin{array}{c}0^{* \dagger \dagger \mathrm{c}} \\
{[0]}\end{array}$ & $\begin{array}{l}1.3^{* \mathrm{*} a} \\
{[2.2]}\end{array}$ & $\begin{array}{c}2.9 * \dot{ } * \mathrm{c} \\
{[5.2]}\end{array}$ & $\begin{array}{l}7.6 * \mathrm{sc} \\
{[7.1]}\end{array}$ & $\begin{array}{c}9.0 * \& b \\
{[6.9]}\end{array}$ & $\begin{array}{l}8.9 * \S \\
{[5.7]}\end{array}$ \\
\hline & NBE & $\begin{array}{c}19.3 \\
{[5.3]}\end{array}$ & $\begin{array}{l}6.0^{*} \\
{[4.8]}\end{array}$ & $\begin{array}{l}1.0^{*} \\
{[2.6]}\end{array}$ & $\begin{array}{l}5.6^{*} \\
{[5.5]}\end{array}$ & $\begin{array}{c}12.8 \\
{[6.5]}\end{array}$ & $\begin{array}{l}14.9^{\S} \\
{[5.9]}\end{array}$ & $\begin{array}{c}11.5 \\
{[6.5]}\end{array}$ & $\begin{array}{c}9.9 \\
{[7.9]}\end{array}$ & $\begin{array}{c}9.4 \\
{[6.3]}\end{array}$ \\
\hline \multirow{2}{*}{ Levo } & BE & $\begin{array}{l}21.1 \\
{[4.2]}\end{array}$ & $\begin{array}{l}4.9^{*} \\
{[6.3]}\end{array}$ & $\begin{array}{c}0.4^{* b} \\
{[1.1]}\end{array}$ & $\begin{array}{c}0^{*+\mathrm{c}} \\
{[0]}\end{array}$ & $\begin{array}{l}1.3 * \mathrm{a} \\
{[3.5]}\end{array}$ & $\begin{array}{l}1.1^{* c} \\
{[2.2]}\end{array}$ & $\begin{array}{c}3.6^{* b, c} \\
{[6.7]}\end{array}$ & $\begin{array}{l}7.0^{* \mathrm{a}} \\
{[7.3]}\end{array}$ & $\begin{array}{c}6.4^{*} \\
{[6.3]}\end{array}$ \\
\hline & NBE & $\begin{array}{l}18.3 \\
{[7.2]}\end{array}$ & $\begin{array}{c}11.3 \\
{[4.8]}\end{array}$ & $\begin{array}{c}2^{*} \\
{[2.3]}\end{array}$ & $\begin{array}{c}10^{*} \\
{[9.2]}\end{array}$ & $\begin{array}{l}18.4 \S \\
{[6.1]}\end{array}$ & $\begin{array}{l}16.3^{\S} \\
{[8.1]}\end{array}$ & $\begin{array}{l}17.4^{\S} \\
{[6.7]}\end{array}$ & $\begin{array}{c}19.1 \\
{[6.1]}\end{array}$ & $\begin{array}{l}15.3 \\
{[6.1]}\end{array}$ \\
\hline
\end{tabular}

* Indicates significant difference from other time points with baseline (T0). ${ }^{\S}$ Indicates significant difference from other time points with TREC. ${ }^{\dagger}$ Indicates significant difference between blocked and control eyes within each treatment over time. ${ }^{\mathrm{a}, \mathrm{b}}$ Indicates significant difference between treatments over time $(P<0.05)$.

Source: Elaboration of the authors.

When evaluated at 12 and $24 \mathrm{~h}$ after the block, pupillary diameter, IOP and tear production presented normal values for dogs in accordance to the literature (SLATTER, 2005). Therefore, these results were not included in tables 1, 2 and 3.

There was a significant difference between treatments in the corneal touch threshold measurements after retrobulbar block (Figure 1). The eyes treated with lidocaine showed a return of corneal sensitivity more rapidly than those treated with levobupivacaine $(P<0.05)$. The mean $\pm \mathrm{SD}$ of the return time (to sensitivity) for lidocaine, ropivacaine, bupivacaine and levobupivacaine were $157.5 \pm 31.05 \mathrm{~min}, 405 \pm 27.77 \mathrm{~min}, 397.5 \pm 31.05$ $\min , 547.5 \pm 148.5 \mathrm{~min}$, respectively. 
Figure 1. Mean $\pm \mathrm{SD}$ of time to return of corneal sensitivity (minutes) of dogs after retrobulbar block with $2 \%$ lidocaine (Lido); 0.75\% ropivacaine (Ropi), 0.5\% bupivacaine (Bupi) or 0.75\% levobupivacaine (Levo). Different letters indicates significant differences between treatments. $(P<0.05)$.

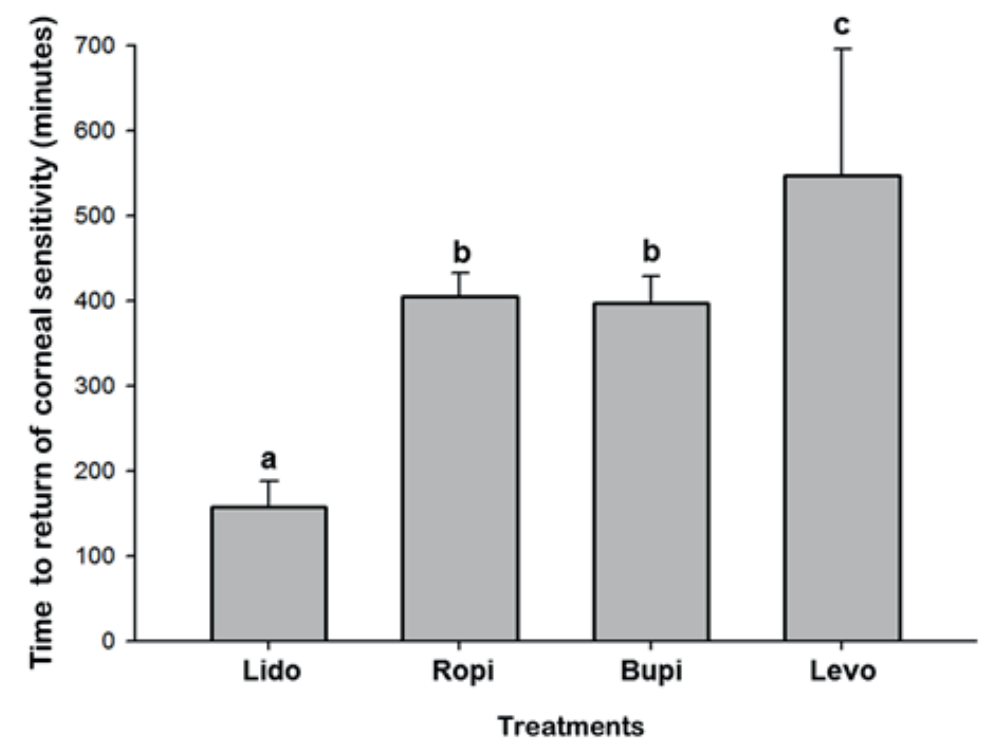

Source: Elaboration of the authors.

\section{Discussion}

The centralization of the eye and maintenance of intraocular pressure are all essential in intraocular surgery (SMITH et al., 2004; HAZRA et al., 2008; OLIVA et al., 2010) and thus have motivated the search for feasible and safe anesthetic techniques for this purpose. Among these techniques, ocular regional blocks are often used in humans, but the procedure is still restricted in small animal veterinary medicine (OLIVA; ANDRADE; GABAS, 2003; ACCOLA et al., 2006; KLAUMANN et al., 2008; OLIVA et al., 2010). Accola et al. (2006) studied three techniques of regional eye anesthesia, including peribulbar and retrobulbar, which motivated additional research (KANEMAKI et al., 2000, SMITH et al., 2004; HAZRA et al., 2008; KLAUMANN et al., 2008; OLIVA et al., 2010). That study also influenced the choice of blocking used in this study.

Based on the study of Accola et al. (2006), in which $2 \mathrm{~mL}$ of local anesthetic was used without complications like excessive exophthalmos, increased IOP or vitreous detachment, the same volume was chosen for the block in this work. Reinforcing this choice, Munger and Ackerman (1978) also found that 1 to $2 \mathrm{~mL}$ was safer than 3 to $4 \mathrm{~mL}$ for retrobulbar injections in dogs, because larger volumes exceeded the capacity of the retrobulbar cone, spilled into the periorbital space and could cause increased retrobulbar pressure on the eye bulb.

The literature mentions that the use of retrobulbar block in cataract surgery may, in addition to its known analgesic and anesthetic purposes (KANEMAKI et al., 2000, SMITH et al., 2004; OLIVA et al., 2010), promote discreet proptosis of the bulb, improving stability and increasing the exposure of the cornea (HAZRA et al., 2008; OLIVA et al., 2010). In this study, the anesthetic volume used proved sufficient to provide anesthesia and analgesia as well as good exposure of the eye bulb, and it performed similarly in all treatments.

Accola et al. (2006) recommended the use of a $22 \mathrm{G}$ spinal needle bent at an angle of approximately $20^{\circ}$ at its midpoint. The Tuohy epidural needle was chosen instead, because it minimizes the risk of 
injury to the dura mater due to the layout of the bevel (FRÖLICH; CATON, 2001). Additionally, when performing the steps of transfixing the eyelid and positioning perpendicularly to the skin, we noted that the intraconal space was not reached. Thus, we opted to introduce the needle with the injector's body positioned parallel to the length of the animal's snout, and it was inclined toward the floor of the orbit until the resistance of the orbital fascia was exceeded. Setting the upper bulbar conjunctiva with a Halsted clamp gave greater firmness, because reaching the periocular tissues with transfixation of the eyelid caused the eye bulb to accompany the movement of the needle, making it difficult to position and introducing the possibility of drilling the eye bulb. However, this procedure may have influenced the high incidence of chemosis observed in the blocked eyes. In one animal, the chemosis was attributed to individual sensitivity and not to the treatment, because the animal's injury was more intense in all treatments.

Various adverse effects and complications arising from retrobulbar block have been described in the literature, including perforation of the eye bulb, conjunctival hemorrhage, chemosis, corneal ulceration, damage to the optic nerve (GILLART; DUALÉ; CURT, 2002; KUMAR; DOWD, 2008), respiratory arrest (RUUSUVAARA; SETÄLÄ; TARKKANEN, 1988), arterio-venous retinal occlusion (TORRES et al., 2005; KUMAR; DOWD, 2008), deafness (GEORGE; HACKETT, 2005), blindness and paralysis of the extraocular muscles (CHINCHURRETA-CAPOTE et al., 2006; KUMAR; DOWD, 2008). Chemosis and corneal ulceration were observed in this study in low ocurrence and they did not hamper blocking or interfere with its effect.

The corneal ulcerations observed in Ropi and Levo may be due to the intensity and duration of reduced tear production in these two treatments, compared to the others, causing severe dryness of the ocular surface which, combined with eyelid akinesia, induced ulceration.
In agreement with the observations in this study, Klaumann et al. (2008) mentioned the occurrence of blepharospasm and ocular itching in animals undergoing peribulbar block with $1 \%$ ropivacaine. In contrast, Mota et al. (2009) and Oliva et al . (2010), who performed the peribulbar block with $0.5 \%$ and $0.75 \%$ ropivacaine in cats and dogs, respectively, did not observed this symptom. Because ropivacaine is considered to be devoid of toxicity (AKERMAN; HELLBERG; TROSSVIK, 1988; LEW; VLOKA; HADŽIC, 2001; TORRES, 2006) even when used for ocular topical anesthesia (MARTINI et al., 2002), we assume that the symptoms observed may be related to the use of drugs of the same origin that differ from those used by Mota et al. (2009) and Oliva et al. (2010).

The pupillary dilation occurred simultaneously with retrobulbar administration of the drugs except in Ropi, in which the latency time was approximately $7 \mathrm{~min}$. This time delay can be attributed to the vasoconstrictive characteristics inherent to the ropivacaine (AKERMAN; HELLBERG; TROSSVIK, 1988; SKARDA, 1996, LEW; VLOKA; HADŽIC, 2001; NOCITI et al., 2001; OLMEZ et al., 2004), which may have prolonged the time to drug absorption and consequently prolonged latency. Mota et al. (2009) also observed (in peribulbar block with $0.5 \%$ ropivacaine in cats) a latency of $10.6 \pm 1.65 \mathrm{~min}$. Moreover, Lew, Vloka and Hadžic (2001) reported that the latency of ropivacaine and bupivacaine compared to similar concentrations of other drugs was lower in laboratory animals and humans; these were controversial results.

In every treatment group, after retrobulbar block, animals maintained an IOP within the reference range. There are references to increased IOP after the use of periocular (SERZEDO et al., 2000; WATKINS et al., 2001; ACCOLA et al., 2006) and retrobulbar blocks (MUNGER; ACKERMAN, 1978; WATKINS et al., 2001; ACCOLA et al., 2006). Although it is unclear how the ocular blood flow changes in response to different regional 
anesthesia techniques and gives rise to this increase (WATKINS et al., 2001; HUBER; REMKY, 2005), it is believed that this the increased in IOP is transient and is triggered by the pressure that the volume of anesthetic injected exerts on the eye bulb (NOCITI et al., 2001; OLMEZ et al., 2004).

The significantly reduced IOP in the Ropi eyes (compared to controls) supports the idea that the relaxation promoted by ropivacaine is more efficient than that triggered by other local anesthetics (SERZEDO et al., 2000; NOCITI et al., 2001; SERZEDO et al., 2001; OLMEZ et al., 2004), because the extraocular muscle relaxation reduces the external pressure on the eye bulb and contributes to the decrease in IOP (MURPHY, 1985; SLATTER, 2005; GUM; GELATT; ESSON, 2007).

The secretion of the lacrimal glands is under the influence of hormonal and neurological control (WILLIAMS, 2008). The neurological control includes sympathetic and parasympathetic innervations, and an arc reflex originating from the corneal sensory nerves are responsible for the activation of the parasympathetic efferent nerve (SHAMIR; OFRI, 2007; WILLIAMS, 2008). The autonomic parasympathetic nervous system is responsible for stimulating actions for the preservation of bodily functions, including the release of tears by the lacrimal glands (DYCE; SACK; WENSING, 1997; MAZZANTI et al., 1999). Thus, the interruption of the efferent limb nerve conduction results in reduced tear production (MAZZANTI et al., 1999; SLATTER, 2005), which seems to have been achieved, because we observed a transient reduction in results of the Schirmer test in all of the blocked eyes.

The tear production in the blocked eyes in all groups, except Lido, began to rise 120 min after the blockade. As the period of action of a local anesthetic is characterized by the contact time of this anesthetic with the nerve (GREENE, 2002) and the volume and concentration used (MAMA; STEFFEY, 2003; MAGALHÃES; GOVÊIA;
OLIVEIRA, 2004), we infer that branches from the facial nerve that address the secretory function of the lacrimal gland would be less subject to the action of anesthetics compared to those responsible for the sensory part of the cornea. In any event, the innervation of the lacrimal gland is not completely understood, and it is known that other nerve branches are involved in its function (SLATTER, 2005; SAMUELSON, 2007), as well as the third eyelid gland which also helps with tear production, although to a lesser extent (SLATTER, 2005; GIULIANO; MOORE, 2007).

With the return of corneal sensitivity, lacrimal production, which had been rising concurrently, reached normal levels in all of the groups. This turnaround time probably involved the restoration of reflex tearing (ORLIN et al., 1989; SLATTER, 2005). An arc reflex is triggered by a corneal stimulus; in other words, trigeminal nucleus neurons receive sensory stimulation of the cornea through the trigeminal ganglion cells and promote a reflex response by stimulation of cells in the facial nerve nucleus. As a result of this reflex arc, the eyelids close and tear production increases (SHAMIR; OFRI, 2007).

Given the above, it is important to emphasize the need for ocular lubricants when using the retrobulbar block. Lubricants are necessary until tear production normalizes and corneal sensitivity returns, especially when levobupivacaine hydrochloride is used, because our results show that lacrimal production was not restored until more than $6 \mathrm{~h}$ after the block.

In the eyes blocked by lidocaine, we observed a decrease in- but not lack of- tear production, which could be explained by the lower potency of this anesthetic compared to the others (MAMA; STEFFEY, 2003; FANTONI; CORTOPASSI; BERNARDI, 2006). When used peribulbarly, Klaumann et al. (2008) reported no interference in tear production with the use of $2 \%$ lidocaine, unlike the results observed in this study. 
The corneal sensitivity remained absent in accordance of the potency of the anesthetic, and the time to return of sensitivity was much higher than the akinesia time, in agreement with the literature (GILLART; DUALÉ; CURT, 2002; MAMA; STEFFEY, 2003; FANTONI; CORTOPASSI; BERNARDI, 2006; OLIVA et al. 2010).

In agreement with the observations of this study, ropivacaine and bupivacaine have been shown to act in similar amounts of time (MAMA; STEFFEY, 2003; FANTONI; CORTOPASSI; BERNARDI, 2006; TORRES, 2006), although ropivacaine is reported to be less toxic and less potent than bupivacaine (ZARIC et al., 1996; TORRES, 2006). The addition of epinephrine to local anesthetics prolongs their effect due to decreased absorption (WONG, 1993; MAMA; STEFFEY, 2003; FANTONI; CORTOPASSI; BERNARDI, 2006). However, in this study, $0.5 \%$ bupivacaine associated with a vasoconstrictor showed the same action time as $0.5 \%$ ropivacaine, confirming the report by Wong (1993) that the addition of adrenaline to bupivacaine does not prolong the time of akinesia and anesthesia. Although bupivacaine is associated with a vasoconstrictor, there were no complications in the bupivacaine group (e.g., the itching or eye discomfort observed in the ropivacaine group).

\section{Conclusions}

The inferior temporal technique for the retrobulbar block proved to be feasible and safe as performed in this trial. All of the anesthetics tested promoted a suitable block. In terms of blocking time, the lidocaine was the fastest-acting anesthetic and levobupivacaine lasted the longest. The proposed anesthetics maintained the IOP within acceptable levels for normal dogs and significantly reduced tear production. With respect to clinical effects, ropivacaine was the anesthetic that most promoted blepharospasm, itching and eye ulceration, although levobupivacaine also promoted corneal ulceration. The use of ocular lubricants may mitigate the long- term effects of corneal dryness, especially when levobupivacaine is used.

\section{Conflict of Interest Statement}

None of the authors have any financial or personal relationship that could inappropriately influence or bias the content of the paper.

\section{Acknowledgements}

This work was supported by grants from FAPESP (Processes $n^{\circ}$ 07/03505-5, 07/04586-9, 07/08403-6).

\section{References}

ACCOLA, P. J.; BENTLEY, E.; SMITH, L. J.; FORREST, L. J.; BAUMEL, C. A.; MURPHY, C. J. Development of a retrobulbar injection technique for ocular surgery and analgesia in dogs. Journal of American Veterinary Medical Association, Ithaca, v. 229, n. 2, p. 220-225, 2006.

AKERMAN, B.; HELLBERG, I. B.; TROSSVIK, C. Primary evaluation of the local anaesthetic properties of the amino amide agent ropivacaine (LEA 103). Acta Anaesthesiologica Scandinavica, Aarhus, v. 32, n. 7, p. 571-578, 1988.

ARVO. Statement For the use of animals in ophthalmic and visual research. 2013. Avaliable at: $<$ http://www.arvo. org/About_ARVO/Policies/Statement_for_the_Use of_Animals_in_Ophthalmic_and_Visual_Research $>$. Acessed at: 30 apr. 2013.

CHINCHURRETA-CAPOTE, A.; BELTRÁN-UREÑA, F. J.; FERNÁNDEZ-RAMOS, M. A.; MARTÍNEZ-DEVELASCO-SANTOS, C. Contralateral amaurosis and extraocular muscle palsies after retrobulbar. Archivos de La Sociedad Española de Oftalmología, Madrid, v. 81, n. 1, p. 45-48, 2006.

COELHO, R. P.; WEISSHEIMER, J.; ROMÃO, E.; CRUZ, A. A. V. Comparação entre a dor provocada pela facoemulsificação com anestesia tópica e a pela infiltração peribulbar sem sedação. Arquivos Brasileiros de Oftalmologia, São Paulo, v. 68, n. 1, p. 45-48, 2005.

COLlinS, B. K.; GROSS, M. E.; MOORE, C. P.; BRANSON, K. R. Physiologic, pharmacologic and practical considerations for anesthesia of domestic 
animals with eye disease. Journal of American Veterinary Medical Association, Ithaca, v. 207, n. 2, p. 220-230, 1995.

DYCE, K. M.; SACK, W. O.; WENSING, C. J. G. Os órgãos dos sentidos. In: Tratado de anatomia veterinária. 2. ed. Rio de Janeiro: Guanabara Koogan, 1997. p. 258-276.

FANTONI, D. T.; CORTOPASSI, S. R. G.; BERNARDI, M. M. Anestésicos locais. In: SPINOSA, H. S.; GÓRNIAK, S. L.; BERNARDI, M. M. Farmacologia aplicada à medicina veterinária. 4. ed. Rio de Janeiro: Guanabara Koogan, 2006. p. 144-151.

FRÖLICH, M. A.; CATON, D. Pioneers in epidural needle design. Anesthesia and Analgesia, Cleveland, v. 93, n. 1, p. 215-220, 2001.

GEORGE, R. B.; HACKETT, J. Bilateral hearing loss following a retrobulbar block. Canadian Journal of Anesthesia, Toronto, v. 52, n. 10, p. 1054-1057, 2005.

GILGER, B. C.; DAVIDSON, M. G. How to prepare for ocular surgery in the standing horse. In: PROCEEDINGS OF THE ANNUAL CONVENTION OF AMERICAN ASSOCIATION OF EQUINE PRACTITIONERS, 48., 2002, Orlando. Proceedings... Orlando: AAEP, 2002. p. 266-271.

GILLART, T.; DUALÉ, C.; CURT, I. Ophthalmic regional anaesthesia. Current Opinion in. Anaesthesiology, Philadelphia, v. 15, n. 5, p. 503-509, 2002.

GIULIANO, E. A.; MOORE, C. P. Diseases and surgery of the lacrimal secretory system. In: GELATT, K. N. Veterinary ophthalmology. $4^{\text {th }}$ ed. Oxford: Blackwell Publishing, 2007. p. 633-661.

GREENE, S. Veterinary anesthesia and pain management secrets. $2^{\text {nd }}$ ed. St. Louis: Elsevier Saunders, 2002. 369 p.

GUM, G. G.; GELATT, K. N.; ESSON, D. W. Physiology of the eye. In: GELATT, K. N. Veterinary ophthalmology. $4^{\text {th }}$ ed. Oxford: Blackwell Publishing, 2007. p. 149-182.

HASKINS, S. C. Monitoring anesthetized patients. In: TRANQUILLI, W. J.; THURMON, J. C.; GRIMM, K. A. Lumb \& Jones' veterinary anesthesia and analgesia. $4^{\text {th }}$ ed. Oxford: Blackwell Publishing, 2007. p. 533-557.

HAZRA, S.; DE, D.; ROY, B.; BOSE, A.; NANDI, S.; KONAR, A. Use of ketamine, xylazine, and diazepam anesthesia with retrobulbar block for phacoemulsification in dogs. Veterinary Ophthalmology, Oxford, v. 11, n. 4, p. 255-259, 2008.

HUBER, K. K.; REMKY, A. Effect of retobulbar versus subconjuntival anaesthesia on retrobular haemodynamics. The British Journal of Ophthalmolology, London, v. 89, n. 6, p. 719-723, 2005.
KANEMAKI, N.; ONO, K.; SUGA, T. WADA, I. Retrobulbar anesthesia of both bupivacaine and lidocaine for intra-ocular surgery in dogs. Veterinary Ophthalmology, Oxford, v. 3, p. 247-257, 2000.

KLAUMANN, P. R.; WOUK, A. F. P. F.; MONTIANIFERREIRA, F.; VILANI, R. G. D. C. Estudo comparativo entre ropivacaína e lidocaína no bloqueio peribulbar em cães. MEDVEP: Revista Cientifica de Medicina Veterinária Pequenos Animais e Animais de Estimação, Curitiba, v. 6, p. 268-277, 2008.

KUMAR, C.; DOWD, T. Ophthalmic regional anaesthesia. Current Opinion in Anaesthesiologia, Philadelphia, v. 21, n. 5, p. 632-637, 2008.

LEW, E.; VLOKA, J. D.; HADŽIĆ, A. Ropivacaine for peripheral nerve blocks: are there advantages? Techniques in Regional Anesthesia \& Pain Management, Philadelphia, v. 5, n. 2, p. 56-59, 2001.

MAGALHÃES, E.; GOVÊIA, C. S.; OLIVEIRA, K. B. Bupivacaína racêmica, levobupivacaína e ropivacaína em anestesia loco-regional para oftalmologia - um estudo comparativo. Revista da Associação Médica Brasileira, São Paulo, v. 50, n. 2, p. 195-198, 2004.

MAMA, K. R.; STEFFEY, E. P. Anestésicos locais. In: ADAMS, H. R. Farmacologia e terapêutica em veterinária. 8. ed. Rio de Janeiro: Guanabara-Koogan, 2003. p. 285-298.

MARTINI, E.; CAVALLINI, G. M.; CAMPI, L.; LUGLI, N.; NERI, G.; MOLINARI, P. Lidocaine versus ropivacaine for topical anesthesia in cataract surgery (1). Journal of Cataract and Refractive Surgery, Fairfax, v. 28, n. 6, p. 1018-1022, 2002.

MAZZANTI, A.; RAISER, A. G.; PIPPI, N. L.; OLIVEIRA, J. C. D.; EURIDES, D.; ANDRADE, C. M. Nervos oculares dos animais domésticos, comparativos e aplicações clínicas. Veterinária Notícias, Uberlândia, v. 5, n. 1, p. 119-130, 1999.

MOTA, F. C. D.; EURIDES, D.; FREITAS, P. M. C.; BELO, M. A. A.; SOARES, V. E.; FATORETTO, L. A. Uso da ropivacaína a $0,5 \%$ em anestesia peribulbar de gatos. Revista Brasileira de Ciência Veterinária, Niterói, v. 16, n. 3, p. 136-140, 2009.

MUIR III, W. W.; HUBBELL, J. A. E.; SKARDA, R. T.; BEDNARSKI, R. M. Handbook of veterinary anesthesia. $4^{\text {th }}$ ed. St. Louis: Elsevier Saunders, 2001. $574 \mathrm{p}$.

MUNGER, R. J.; ACKERMAN, N. Retrobulbar injections in the dog: a comparison of three techniques. Journal of the American Animal Hospital Association, Denver, v. 14, n. 4, p. 490-498, 1978. 
MURPHY, D. F. Anesthesia and intraocular pressure. Anesthesia and Analgesia, Cleveland, v. 64, n. 5, p. 520530, 1985.

NOCITI, J. R.; SERZEDO, P. S. M.; ZUCCOLOTTO, E. B.; NUNES, A. M. M.; FERREIRA, S. B. Intraocular pressure and ropivacaine in peribulbar block: intraocular pressure and ropivacaine in peribulbar block. Acta Anaesthesiologica Scandinava, Aarhus, v. 45, n. 5, p. 600-602, 2001.

OLIVA, V. N. L. S.; ANDRADE, A. L.; BEVILACQUA, L.; MATSUBARA, L. M.; PERRI, S. H. V. Anestesia peribulbar com ropivacaína como alternativa ao bloqueio neuromuscular para facectomia em cães. Arquivo Brasileiro de Medicina Veterinária e Zootecnia, Belo Horizonte, v. 62, n. 3, p. 586-595, 2010.

OLIVA, V. N. L. S.; ANDRADE, A. L.; GABAS, D. T. Bloqueio anestésico do ramo oftálmico do nervo trigêmeo para procedimentos oftálmicos em cães. Veterinária Notícias, Uberlândia, v. 9, n. 2, p. 31-36, 2003.

OLIVA, V.N.L. S.; BEVILACQUA, L. Anestesia regional em cabeça. In: ENCONTRO DE ANESTESIOLOGIA VETERINÁRIA, 7., 2005, São Luís. Anais... Campos dos Goytacazes: CBCAV, 2005. p. 98-108.

OLMEZ, G.; CAKMAK, S. S.; CACA, I.; UNLU, M. $\mathrm{K}$. Intra-ocular pressure and quality of blockade in peribulbar anesthesia using ropivacaine or lidocaine with adrenaline: a double-blind randomized study. The Tohoku Journal of Experimental Medicine, Sendai, v. 204, n. 3, p. 203-208, 2004.

ORLIN, S.E.; KURATA, F.K.; KRUPIN, T.; SCHNEIDER, M.; GLENDRANGE, R. R. Ocular Lubricants and Corneal Injury during Anesthesia. Anesthesia and Analgesia, Cleveland, v. 69, n. 3, p. 384-385, 1989.

PIRES, J. S.; CAMPELlO, R. A. V.; FARIA, R. X.; GUEDES, A. G. P. Anestesia por infusão contínua e propofol em cães pré-medicados com acepromazina e fentanil. Ciência Rural, Santa Maria, v. 30, n. 5, p. 829834, 2000.

RUUSUVAARA, P.; SETÄLÄ, K.; TARKKANEN, A. Respiratory arrest after retrobulbar block. Acta Ophthalmologica, Copenhagen, v. 66, n. 2, p. 223-225, 1988.

SAMUELSON, D. A. Ophthalmic anatomy. In: GELATT, K. N. Veterinary ophthalmology. $4^{\text {th }}$ ed. Oxford: Blackwell Publishing, 2007. p. 37-148.

SERZEDO, P. S. M.; NOCITI, J. R.; ZUCCOLOTTO, E. B.; SCALCO, T. L.; FERREIRA, S. B. Bloqueio peribulbar com ropivacaína: influência da hialuronidase sobre a qualidade do bloqueio e a pressão intra-ocular.
Revista Brasileira de Anestesiologia, Rio de Janeiro, v. 51, n. 3, p. 202-207, 2001.

SERZEDO, P. S. M.; NOCITI, J. R.; ZUCCOLOTTO, E. B.; SCALCO, T. L.; FERREIRA, S. B. Pressão intraocular durante bloqueio peribulbar com ropivacaína a 1\%. Revista Brasileira de Anestesiologia, Rio de Janeiro, v. 50, n. 3, p. 251-253, 2000.

SHAMIR, M. H.; OFRI, R. Comparative neuroophthalmology. In: GELATT, K. N. Veterinary ophthalmology. $4^{\text {th }}$ ed. Oxford: Blackwell Publishing, 2007. p. 1406-1469.

SKARDA, R. T. Local and regional anesthetic and analgesic techniques: dogs. In: THURMON, J. C.; TRANQUILLI, W. J.; BENSON, G. J. Lumb \& Jones' veterinary anesthesia. $3^{\text {rd }}$ ed. Baltimore: Williams and Wilkins, 1996. p. 426-447.

SLATTER, D. Fundamentos de oftalmologia veterinária. 3. ed. São Paulo: Roca, 2005. 686 p.

SMITH, L. J.; BENTLEY, E.; SHIH, A.; MILLER, P. E. Systemic lidocaine infusion as an analgesic for intraocular surgery in dogs: a pilot study. Veterinary Anaesthesia and Analgesia, Oxford, v. 31, n. 1, p. 53-63, 2004.

TORRES, M. L. A. Toxicidade dos anestésicos locais: o debate continua! Revista Brasileira de Anestesiologia, Rio de Janeiro, v. 56, n. 4, p. 339-342, 2006.

TORRES, R. J. A.; LUCHINI, A.; WEIS, W.; FRECCEIRO, P. R.; CASELLA, M. Oclusão artériovenosa da retina após bloqueio retrobulbar - Relato de dois casos. Arquivo Brasileiro de Oftalmologia, São Paulo, v. 68, n. 2, p. 257-261, 2005.

WATKINS, R.; BEIGI, B.; YATES, M.; CHANG, B.; LINARDOS, E. Intraocular pressure and pulsatile ocular blood flow after retrobulbar and peribulbar anaesthesia. The British Journal of Ophthalmology, London, v. 85, n. 7, p. 796-798, 2001.

WILLIAMS, D. Immunopathogenis of keratoconjunctivitis sicca in the dog. The Veterinary Clinics of North America. Small Animal Practice, Philadelphia, v. 38, n. 2, p. 251-268, 2008.

WONG, D. H. W. Regional anaesthesia for intraocular surgery. Canadian Journal of Anaesthesia, Winnipeg, v. 40, n. 7, p. 635-657, 1993.

ZARIC, D.; NYDAHL, P. A.; PHILIPSON, L.; SAMUELSSON, L.; HEIERSON, A.; AXELSSON, $\mathrm{K}$. The effect of continuous lumbar epidural infusion of ropivacaine $(0.1 \%, 0.2 \%$, and $0.3 \%)$ and $0.25 \%$ bupivacaine on sensory and motor block in volunteers. Regional Anesthesia, Greenwich, v. 21, n. 1, p. 14-25, 1996. 
